Check for updates

Cite this: Med. Chem. Commun., 2018, 9, 2037

Received 27th June 2018,

Accepted 30th September 2018

DOI: $10.1039 / c 8 m d 00319 j$

rsc.li/medchemcomm

\section{Screening of the Pathogen Box reveals new starting points for anti-trypanosomal drug discovery $\dagger$}

\author{
Clinton G. L. Veale (iD ${ }^{a}$ and Heinrich C. Hoppe (iD ${ }^{b}$
}

This study aimed to uncover new starting points for anti-trypansomal drug discovery through the screening of the Pathogen Box against Trypanosoma brucei brucei. Our study identified compounds 35, 39, 46, 53 and 56 whose activity and selectivity highlighted them as promising candidates with potential for further study and optimisation.

\section{Introduction}

Human African trypanosomiasis (HAT), commonly referred to as sleeping sickness whose causative agent is Trypanosoma brucei (T.b.), impacts roughly 70 million people living in subSaharan Africa, affecting these populations from both a health and economic perspective. ${ }^{1,2}$ With no current vaccine and limited access to appropriate facilities for early diagnosis, coupled to treatment regimens which are limited in their scope and efficacy, ${ }^{3,4}$ the importance of stimulating new drug discovery programs through cost effective means is of grave importance. ${ }^{5}$ HAT is caused by the T.b. sub-species T.b. rhodesiense and T.b. gambiense respectively, while African animal trypanosomiasis (AAT) is typically caused by the T.b. brucei subspecies. ${ }^{6,7}$ While T.b. sub-species infections are clinically distinct, they share large similarities in both their molecular and cellular biology, ${ }^{8}$ which has allowed for T.b. brucei to be used as a competent proxy for the identification of hits and leads for HAT. ${ }^{9-12}$ The Pathogen Box like the Malaria Box represents a 400 strong library of compounds with demonstrated biological activity against a range of neglected tropical diseases, ${ }^{13}$ which has formed the basis of numerous screening campaigns to identify chemical starting points for hit and lead optimisation campaigns. ${ }^{14-16}$ Van Voorhis et al. ${ }^{13}$ reported a meta-analysis of multiple screens of the Malaria Box, which included antitrypanosomal hit compounds. Similarly, in our efforts to identify new starting points for anti-trypanosomal drug discovery, we screened the Pathogen Box against T.b. brucei and identified a handful of compounds with encouraging and selective in vitro activity. During the process of our screening campaign, we were alerted to a study by Duffy et al. in which they

\footnotetext{
${ }^{a}$ School of Chemistry and Physics, Pietermaritzburg Campus, University of KwaZulu-Natal, Private Bag X01, Scottsville, 3209, South Africa.

E-mail:VealeC@ukzn.ac.za; Tel: +27332606365

${ }^{b}$ Department of Biochemistry and Microbiology, Rhodes University, Grahamstown, 6140, South Africa. E-mail: H.Hoppe@ru.ac.za; Tel: +27 466038262

$\dagger$ Electronic supplementary information (ESI) available. See DOI: 10.1039/c8md00319j
}

performed a comprehensive screen of the Pathogen Box against multiple protozoan parasites including T.b. brucei. ${ }^{17}$ This current study and that of Duffy et al. used different criteria, from which to select compounds for dose-dependent analysis, therefore, in some instances an $\mathrm{IC}_{50}$ value may not have been determined for a compound from either study. However, a lack of an $\mathrm{IC}_{50}$ value does not necessarily mean that a compound was inactive, but rather that it was likely a moderate inhibitor. In addition, false positives and negatives are a burden of screening campaigns, ${ }^{18,19}$ therefore, for the purposes of robust analysis, we took this opportunity to compare our data with that obtained by Duffy et al. as well as that originally reported in the Pathogen Box. The majority of data we obtained in our study correlated well with that reported previously, particularly with respect to compounds from the kinetoplastid category of the Pathogen Box, which provided confidence in our method as well as for the previously reported data. However, inhibitory data for a small cohort of compounds from other categories of the pathogen differed to that reported by Duffy et al. Accordingly, we report our findings as an independent analysis of the Pathogen Box, which highlights potential new starting points for anti-trypanosomal drug discovery.

\section{Results and discussion}

Prior to subjecting compounds to dose-dependent assessments, the Pathogen Box was screened for T.b. brucei inhibitory activity at a single concentration $(10 \mu \mathrm{M})$. Compounds which inhibited cell viability to below $20 \%$ (i.e. reduced cell viability by $80 \%$ or more) at this concentration were put forward for dose dose-dependent assessment.

We opted for fairly stringent exclusion criteria, since the principal aim of this study was to identify or confirm compounds with activity in the sub-micromolar range. This data is supplied in the supplementary information. Of the $70 \mathrm{com}$ pounds categorised in the Pathogen Box as active against kinetoplastids, 34 were classified as inhibitors of T.b. brucei. Of 
these, 29 compounds (1-22, 25, 28-31, 33, 34) met our exclusion threshold and were subjected for $\mathrm{IC}_{50}$ evaluation (Table 1 ). In order to assess the robustness of our screen, we plotted $\mathrm{pIC}_{50}$ values (M) from the Pathogen Box vs. our experimentally obtained values (Fig. 1). Inhibitory data which was not provided as a precise value, but rather as an approximation below a threshold (i.e. $<0.13 \mu \mathrm{M}$ ) was left out of our initial plot. Gratifyingly, this data showed that in all instances where $\mathrm{IC}_{50}$ data was obtained, the difference in $\mathrm{pIC}_{50}$ was lower than 1 (an order of magnitude). However, five compounds (15, 17, 19, 20, 21) differed by greater than $0.5 \log$ units. Five compounds (23, $24,26,27,32$ ) appeared on the base on the $x$-axis, and represent compounds which did not sufficiently reduce cell viability in our single concentration screen, and were not subjected to $\mathrm{IC}_{50}$ analysis. However, of these compounds, only compound 24 (MMV688776) had activity in the sub-micromolar range reported in the Pathogen Box. The same plot was obtained by comparing the data of Duffy et al. and ours (Fig. 1). In this instance a change in $\mathrm{pIC}_{50}$ of greater than $0.5 \mathrm{log}$ units was observed for six compounds $(1,4,7,15,21,29)$ with only com- pound 1 (MMV688180) displaying a change in $\mathrm{pIC}_{50}$ greater than 1. However, this was a significant outlier. Compound 1 has previously been reported as a moderate inhibitor of $T$. brucei culture through the selective inhibition of $T$. brucei $N$-myristoyl transferase. ${ }^{20,21}$

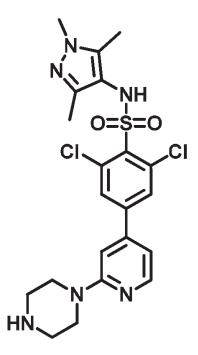

1. MMV688180<smiles>Cc1nn2c(=O)c3c([nH]c2c1-c1ccc(Cl)cc1)CCCC3</smiles>

24. MMV688776

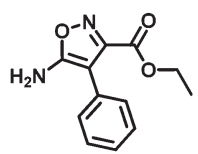

34. MMV1236379
None of the other five compounds for which we obtained no $\mathrm{IC}_{50}$ values $(23,24,26,27,32)$ inhibited T.b. brucei below 1

Table 1 In vitro activity of the kinetoplastid category of the Pathogen Box against T.b. brucei

\begin{tabular}{|c|c|c|c|c|c|}
\hline \multirow{2}{*}{$\begin{array}{l}\text { Cpd } \\
\text { no. }\end{array}$} & \multirow[b]{2}{*}{ ID } & \multicolumn{3}{|c|}{ T. brucei brucei $\mathrm{IC}_{50}(\mu \mathrm{M})$} & \multirow{2}{*}{$\begin{array}{l}\text { HeLa } \\
\text { IC }_{50}(\mu \mathrm{M})\end{array}$} \\
\hline & & Duffy et $a l^{a}$ & Pathogen Box $^{b}$ & This study & \\
\hline 1 & MMV688180 & 0.01 & $<0.13$ & 11 & 2.8 \\
\hline 2 & MMV688372 & 0.02 & $<0.13$ & 0.049 & 0.8 \\
\hline 3 & MMV652003 & 0.11 & 0.15 & 0.14 & $>25$ \\
\hline 4 & MMV688550 & 0.13 & $<0.13$ & 0.030 & $>25$ \\
\hline 5 & MMV688797 & 0.13 & 0.13 & 0.050 & $>25$ \\
\hline 6 & MMV676604 & 0.14 & 0.26 & 0.084 & 1.2 \\
\hline 7 & MMV676602 & 0.17 & $<0.13$ & 0.048 & 4.0 \\
\hline 8 & MMV688796 & 0.23 & 0.10 & 0.11 & $>25$ \\
\hline 9 & MMV688371 & 0.24 & $<0.13$ & 0.49 & 7.5 \\
\hline 10 & MMV688958 & 0.24 & 0.15 & 0.18 & $>25$ \\
\hline 11 & MMV689028 & 0.24 & 0.14 & 0.12 & $>25$ \\
\hline 12 & MMV675998 & 0.27 & 0.25 & 0.54 & $>25$ \\
\hline 13 & MMV688795 & 0.27 & 0.15 & 0.21 & $>25$ \\
\hline 14 & MMV688798 & 0.50 & 0.56 & 1.2 & $>25$ \\
\hline 15 & MMV690027 & 0.50 & 0.02 & 0.12 & $>25$ \\
\hline 16 & MMV688271 & 0.52 & 0.60 & 0.65 & 17 \\
\hline 17 & MMV202553 & 1.0 & 2.46 & 0.38 & $>25$ \\
\hline 18 & MMV689029 & 1.1 & 0.50 & 0.44 & $>25$ \\
\hline 19 & MMV688467 & 1.2 & 0.26 & 1.3 & $>25$ \\
\hline 20 & MMV688793 & 1.2 & 2.07 & 0.62 & $>25$ \\
\hline 21 & MMV676600 & 1.3 & 1.02 & 0.30 & $>25$ \\
\hline 22 & MMV188296 & 1.5 & 0.49 & 0.71 & $>25$ \\
\hline 23 & MMV687762 & 1.8 & 7.58 & ND & ND \\
\hline 24 & MMV688776 & 1.8 & 0.50 & ND & ND \\
\hline 25 & MMV690028 & 2.3 & 0.79 & 1.7 & $>25$ \\
\hline 26 & MMV688514 & 3.5 & 4.06 & ND & ND \\
\hline 27 & MMV595321 & 4.3 & 5.30 & ND & ND \\
\hline 28 & MMV099637 & 4.4 & 1.94 & 4.6 & $>25$ \\
\hline 29 & MMV688279 & 4.5 & 0.98 & 0.98 & 15 \\
\hline 30 & MMV687706 & 5.1 & 0.99 & 2.3 & 11 \\
\hline 31 & MMV688283 & 5.3 & 3.78 & 2.2 & $>25$ \\
\hline 32 & MMV688179 & 5.7 & 1.03 & ND & ND \\
\hline 33 & MMV001561 & 6.2 & 3.97 & 4.1 & 10 \\
\hline \multirow[t]{3}{*}{34} & MMV1236379 & $\mathrm{ND}^{c}$ & 1.22 & 0.41 & $>25$ \\
\hline & Pentamidine & & & 0.0031 & \\
\hline & Emetine & & & & 0.4 \\
\hline
\end{tabular}

$\mathrm{IC}_{50}$ values are the mean of experiments conducted in technical triplicate. ${ }^{a}$ Data reported in ref. $17 .{ }^{b}$ Data available at https://www. pathogenbox.org/. ${ }^{c} \mathrm{ND}=$ not determined. 


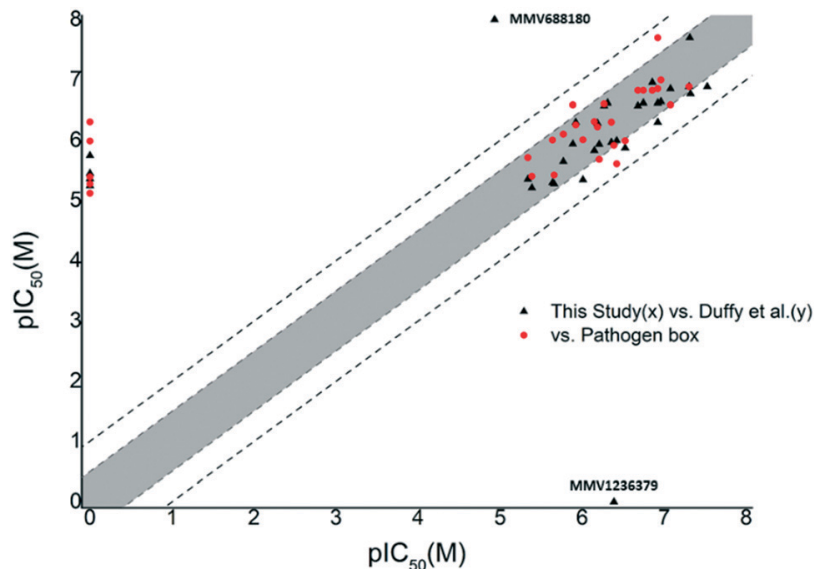

Fig. 1 Plot of $\mathrm{plC}_{50}$ (T.b. brucei) data obtained in this study $(x)$ vs. the Pathogen Box or Duffy et al. (y) from compounds in the kinetoplastid category of the Pathogen Box. Compounds falling outside the grey shaded area differed in $\mathrm{plC}_{50}$ by 0.5 log units or more. Compounds falling outside the dashed lines differed by 1 log unit or more. This figure indicated that our data was in good agreement with previous reports.

$\mu \mathrm{M}$ in Duffy et al.'s screen, and were not considered by us to have potent activity.

While Duffy et al. did not obtain an $\mathrm{IC}_{50}$ value for compound 34 (MMV1236379), our data suggested that 34 was a mid-nanomolar inhibitor of T.b. brucei, while the Pathogen Box placed it at the low micromolar range. While there were several instances, where compound potency differed by more than $0.5 \log$ units, the comparative data obtained in this screen indicated that for the large majority of compounds, the $\mathrm{pIC}_{50}$ values we obtained fall within a 0.5-1 log range when compared to the Pathogen Box and Duffy et al. which we defined as an acceptable degree of similarity with previously reported data. With the exception of 1, 24 and 34 , the majority of compounds whose data did not match to at least within an order of magnitude were compounds which were not subjected to dose-dependent analysis due to those compounds not conforming to our criteria in the single concentration screen (cell viability $\leq 20 \%$ ). The data of Duffy et al. as well as the Pathogen Box, show that these were all low micromolar inhibitors, of T.b. brucei possibly accounting for their moderate performance in the single concentration screen, which indicated that overall, our screening method was robust. The correlation of our screening results and that of Duffy et al. highlights the complexities associated with the confirmation of biological activity and should also be seen in the context of differences in the detailed assay methodology employed. We used 96-well as opposed to 384-well plates, and compounds were incubated with parasites for 48 hours at $37{ }^{\circ} \mathrm{C}$, while Duffy et al. added an additional 2 hours at $37^{\circ} \mathrm{C}$ and 22 hours at room temperature.

From screening the remainder of the Pathogen Box listed for indications other than kinetoplastids, we identified 28 compounds (35-62), which satisfied our single concentration screening criteria, while several compounds (63-69) for which Duffy et al. obtained $\mathrm{IC}_{50}$ data, did not fit our criteria. (Table 2). The remainder of the Pathogen Box was inactive in both screens. Of compounds 63-69, only the antimycobacterial 66 (MMV687807) whose MOA has been speculated to occur via disruption of mitochondrial proton gradient $^{22}$ was reported by Duffy et al. as a sub-micromolar inhibitor of T.b. brucei. Similarly, we obtained $\mathrm{IC}_{50}$ data for 13 compounds $(38,39,43-47,49,53,55,59,60,62)$, which were not reported by Duffy et al. likely due to their own cut off criteria of $5 \mu \mathrm{M}$ in the primary screen. Of these compounds, 39 (MMV676477), 46 (MMV687812) and 53 (MMV010576) were identified as sub-micromolar inhibitors of T.b. brucei. The anti-mycobacterial compound 39 (ref. 23) has yet to be reported as an anti-trypanosomal. However, the closely related analogue TCMDC 142497 (70) was identified from a screen of 1.8 million compounds as a potent kinetoplastid inhibitor. $^{24}$

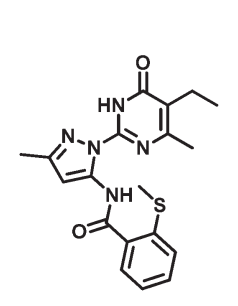

39. MMV676477

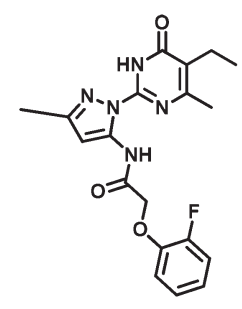

70. TCMDC 142497

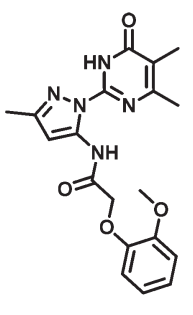

71.<smiles>CN1CCN(CCCOc2ncc(Nc3ncc(-c4ccc(C(F)(F)F)c(F)c4)nc3C(N)=O)cn2)CC1</smiles>

46. MMV687812
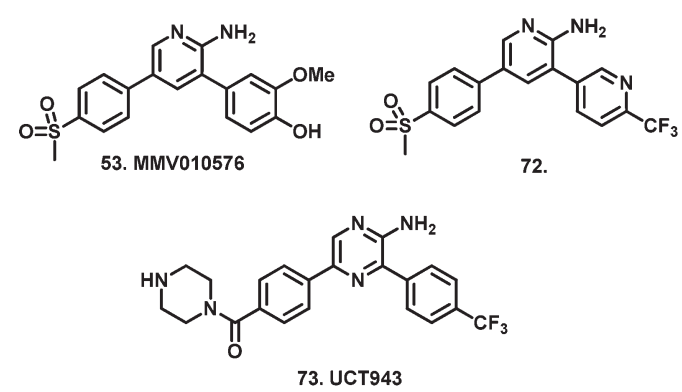

Another analogue (71) has been identified as an inhibitor of neuroblastoma, through the inhibition of the tyrosine kinase TrkB. ${ }^{25}$ Tyrosine kinases have been identified as potential targets for the inhibitions of $T$. brucei. ${ }^{26}$ Compound 46 was identified as a potent in vitro anti-mycobacterial which inhibits the ATPase domain of DNA gyrase B. ${ }^{27}$ Inhibition of DNA gyrase has been shown as an effective means of inhibiting kinetoplastid viability. ${ }^{28,29}$ The 3,5diaryl-2-aminopyridine (53) has previously been identified as a potential inhibitor of $P$. falciparum transmission. ${ }^{30}$ Furthermore, it was found to be a potent and selective 
Table 2 In vitro activity of the remaining Pathogen Box against T.b. brucei

\begin{tabular}{|c|c|c|c|c|c|}
\hline \multirow{2}{*}{$\begin{array}{l}\text { Cpd } \\
\text { no. }\end{array}$} & \multirow[b]{2}{*}{ ID } & \multicolumn{3}{|c|}{ T. brucei brucei $\mathrm{IC}_{50}(\mu \mathrm{M})$} & \multirow{2}{*}{$\begin{array}{l}\text { Selectivity } \\
\text { index }^{c}\end{array}$} \\
\hline & & Duffy et $a l^{a}$ & This study & HeLa IC Io $_{50}(\mu \mathrm{M})$ & \\
\hline 35 & MMV021013 & 3.51 & 0.83 & $>25$ & 30 \\
\hline 37 & MMV153413 & 2.99 & 11 & $>25$ & 2.2 \\
\hline 38 & MMV461553 & $\mathrm{ND}^{b}$ & 11 & $>25$ & 2.2 \\
\hline 39 & MMV676477 & ND & 0.59 & 2.6 & 4.4 \\
\hline 42 & MMV687273 & 2.28 & 2.3 & 15 & 6.5 \\
\hline 43 & MMV676409 & ND & 2.9 & $>25$ & 8.6 \\
\hline 44 & MMV687703 & ND & 4.2 & 22 & 5.2 \\
\hline 45 & MMV687765 & ND & 5.1 & $>25$ & 4.9 \\
\hline 46 & MMV687812 & ND & 0.87 & 4.8 & 5.5 \\
\hline 47 & MMV688844 & ND & 29 & $>25$ & 0.8 \\
\hline 48 & MMV675968 & 2.07 & 1.2 & $>25$ & 21 \\
\hline 53 & MMV010576 & ND & 0.33 & $>25$ & 76 \\
\hline 54 & MMV019189 & 4.68 & 1.0 & 6.6 & 6.6 \\
\hline 55 & MMV020391 & ND & 6.5 & 12 & 1.8 \\
\hline 56 & MMV022029 & 2.38 & 0.22 & 13 & 59 \\
\hline 57 & MMV023233 & 3.29 & 1.2 & 5.4 & 4.5 \\
\hline 58 & MMV028694 & 2.39 & 1.5 & $>25$ & 17 \\
\hline 59 & MMV1030799 & ND & 7.1 & $>25$ & 3.5 \\
\hline 60 & MMV002817 & ND & 2.0 & $>25$ & 13 \\
\hline 61 & MMV688761 & 3.49 & 11 & $>25$ & 2.3 \\
\hline 62 & MMV637229 & ND & 3.5 & $>25$ & 7.1 \\
\hline 63 & MMV272144 & 4.12 & ND & ND & \\
\hline 64 & MMV495543 & 5.45 & ND & ND & \\
\hline 65 & MMV687248 & 1.05 & ND & ND & \\
\hline
\end{tabular}

$\mathrm{IC}_{50}$ values are the mean of experiments conducted in technical triplicate. ${ }^{a}$ Data reported in ref. $17 .{ }^{b}$ ND $=$ not determined. ${ }^{c}$ Selectivity index calculated as $\mathrm{IC}_{50}(\mathrm{HeLa}) / \mathrm{IC}_{50}(T . b b)$.

anti-plasmodial from a screen of the SoftFocus kinase library whose optimisation led to the identification of compound 72 which was curative in murine $P$. berghei following a single orally administered dose, ${ }^{31}$ and is currently undergoing clinical trials. ${ }^{32}$ Importantly, compound 72 was found to inhibit multiple malaria life stages, through its activity at Plasmodium phosphatidylinositol 4-kinase (PI4K), which is responsible for the regulation of intra- cellular signalling and trafficking through lipid phosphorylation. $^{33,34}$ Trypanosomal PI4Ks have been shown to be essential for protein trafficking, Golgi structure, cytokinesis and normal cellular shape, and have been proposed as potential targets for trypanosomal drug discovery. ${ }^{35,36} \mathrm{Re}-$ cently, further optimisation resulted in the identification of pre-clinical candidate 73 (UCT943), which is an improved multistage inhibitor of $P$. falciparum. ${ }^{37,38}$ Furthermore, Duffy et al. identified 53 as a moderate inhibitor of Leishmaniasis donovani.
Comparison of remaining $\mathrm{pIC}_{50}$ values again showed that the majority of compounds did not differ by more than 0.5 $\log$ units from the values reported by Duffy et al. In our screen, the $\mathrm{pIC}_{50}$ of compound 37 (MMV153413) was found to be more than $0.5 \mathrm{log}$ units lower than that reported by Duffy et al. (Fig. 2). However, our moderate inhibitory data for 37 matched that of its close analogue 38 (MMV461553), for which Duffy et al. did not obtain $\mathrm{IC}_{50}$ data. Both of these compounds specifically inhibit mycobacterial cell wall synthesis $^{39}$ likely through the inhibition of mycolic acid biosynthesis. ${ }^{40}$ The remaining four compounds whose $\mathrm{pIC}_{50}$ values differed by more than $0.5 \log$ units $(35,40,54,56)$ were all found to have $\mathrm{pIC}_{50}$ values greater than six, corresponding to sub-micromolar inhibition. Compounds 35 (MMV021013) $^{23}$ and 56 (MMV022029) $^{41}$ had been identified as promising anti-mycobacterial and anti-plasmodial compounds respectively from large scale screening, without compelling evidence for a biological target. 


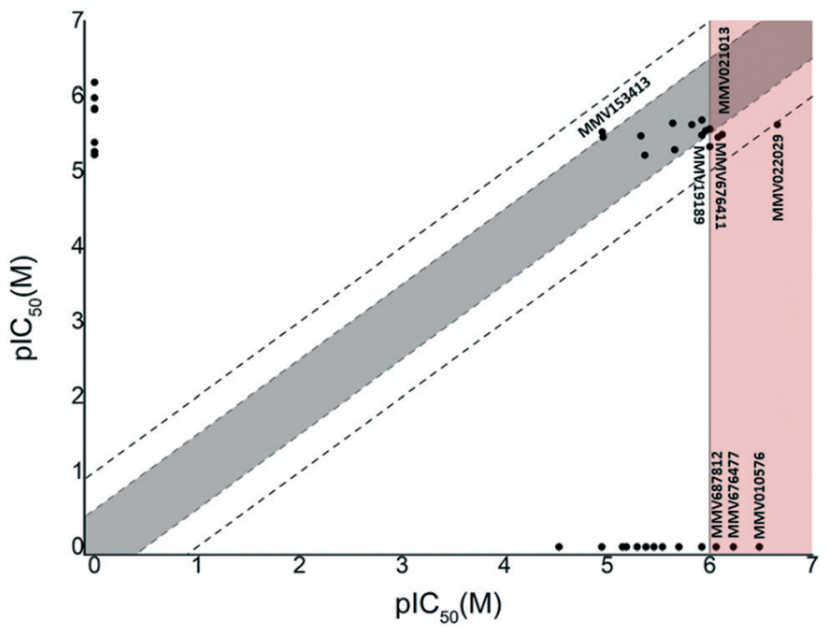

Fig. 2 Plot of $\mathrm{plC}_{50}$ (T.b. brucei) data obtained in this study $(x)$ vs. Duffy et al. $(y)$ from the reminder of the Pathogen Box. Compounds falling outside the grey shaded area differed in $\mathrm{plC}_{50}$ by $0.5 \mathrm{log}$ units or more. Compounds falling outside the dashed lines differed by $1 \mathrm{log}$ unit or more. The pink shaded area highlights compounds which inhibited T.b. brucei in the sub-micromolar range in our screen. Compounds $35,39,40,46,53,54$ and 56 were all found in this area and either differed $0.5 \mathrm{log}$ units or more, or $\mathrm{IC}_{50}$ data was not determined for them by Duffy et al.

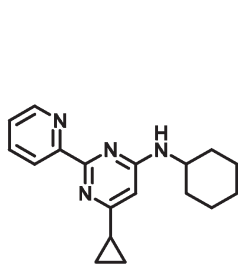

35. MMV021013

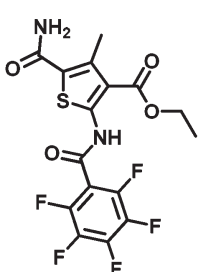

37. MMV153413

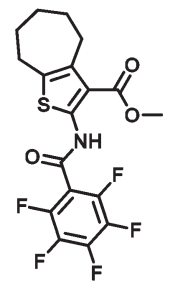

38. MMV461553

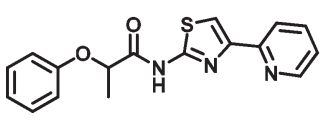

40. MMV676411<smiles>O=C(Nc1ccccc1)c1ccc(-c2cc3ccncc3cc2OC2CCNCC2)s1</smiles>

51. MMV024035<smiles>O=C1N(Cc2cccc3ccccc23)c2ccccc2C12NN=C(c1ccccc1)S2</smiles>

75.<smiles>O=C(COc1cccc(F)c1)Nc1nc(-c2ccccn2)cs1</smiles>

43. MMV676409

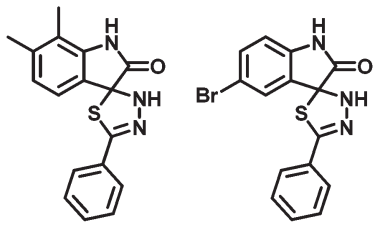

54. MMV019189 74. Lipofermata

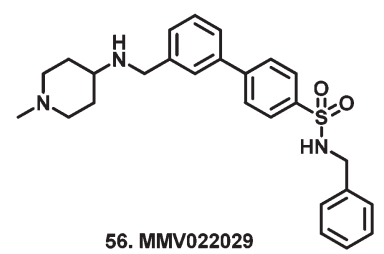

However, compound 40 (MMV676411) and its Pathogen Box analogue 43 (MMV676409) were identified as moderate inhib-

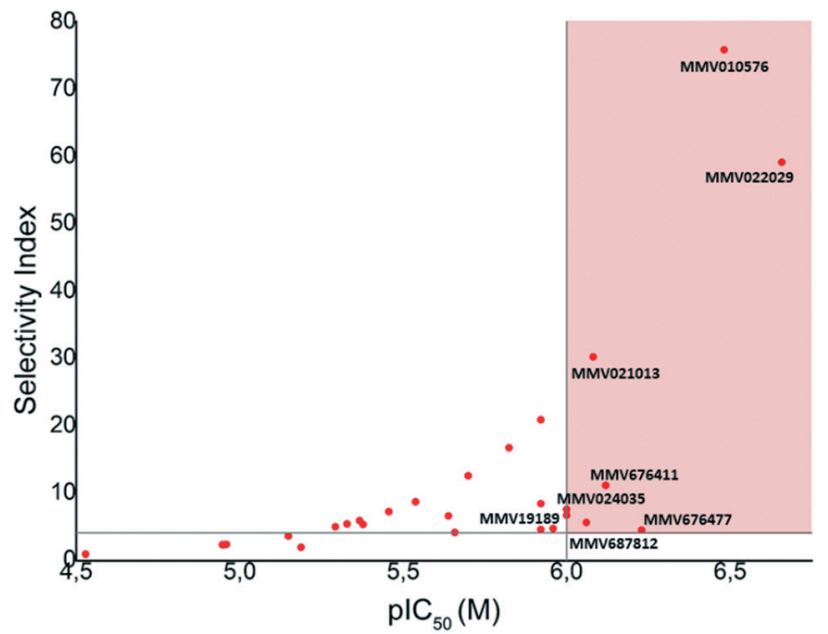

Fig. 3 Plot of $\mathrm{plC}_{50}$ (T.b. brucei) data obtained in this study $(x)$ vs. selectivity index $(y)$ from the reminder of the Pathogen Box. Compounds appearing in the pink shaded area combined submicromolar activity with acceptable selectivity over a HeLa cell line. Compounds 35, 39, 40, 46, 51, 53, 54, and 56 were all deemed to be promising compounds for further study based on this assessment.

itors of M. tuberculosis CTP synthase, PyrG, which is responsible for the committed final step in pyrimidine biosynthesis. ${ }^{42}$ While trypanosomes possess similar machinery for the de novo synthesis of pyrimidines, they are also capable of pyrimidine salvaging, thereby limiting the use of this targeting strategy in vivo. ${ }^{43,44}$ However, this does not exclude the possibility of 40 inhibiting an alternative target.

Compound 54 (MMV019189) had also previously been reported as an anti-plasmodial agent. ${ }^{41}$ While to date there have been no reports of a potential mechanism of action for $\mathbf{5 4}$, the structurally related compounds 74 (Lipofermata) and 75 have been identified as inhibitors of human fatty acid transport protein (FATP2) ${ }^{45}$ and metallo- $\beta$-lactamase. ${ }^{46}$ How- $^{-}$ ever, it is unclear whether analogous targets are present in $T$. brucei.

Having determined cytotoxicity against a HeLa cell line, we were able to derive the selectivity index (SI) for all active compounds (Table 2). A plot of $\mathrm{pIC}_{50} v s$. SI allowed us to rapidly identify which compounds combined good activity $\left(\mathrm{pIC}_{50}\right.$ $>6$ ) with acceptable selectivity (SI $>4$ ) (Fig. 3). Compounds $35,39,40,46,53,54$, and 56 which have been discussed previously, all satisfied these criteria. Of these compounds, 39 and 46 are respectively reported to have $\mathrm{CC}_{50}$ values of 1.3 $\mu \mathrm{M}$ and $3.9 \mu \mathrm{M}$ against HepG2 cells by the Pathogen Box, which agrees with our respective values of $2.6 \mu \mathrm{M}$ and $4.8 \mu \mathrm{M}$ against HeLa cells. While these compounds are very close to our selectivity index cut-off of 4 , their encouraging activity may warrant further investigation and SAR analysis. None of the other compounds were reported as cytotoxic against HepG2 cells in the Pathogen Box dataset. Furthermore, antimalarial compound $51^{41}$ (MMV024035) was identified as a candidate that selectively inhibited T.b. brucei, albeit moderately. This compound also showed moderate inhibition in the screen of Duffy et al. 


\section{Conclusions}

In conclusion, this study sought to identify new starting points for anti-trypanosomal drug discovery, through the repurposing of the Pathogen Box. Our results have identified eight compounds, which may hold promise as starting points for in-depth SAR studies. Compounds 35, 53 and 56 in particular combined activity in the nanomolar range coupled to good selectively, while compounds 39, 46 and 53 again hold potential for target based programs due to their reported activity against targets for which analogous biological processes are present in T. brucei.

\section{Experimental procedures}

\section{Trypanosoma brucei assay}

T.b. brucei (strain 427) bloodstream form parasites were cultured at $37{ }^{\circ} \mathrm{C}$ in a $5 \% \mathrm{CO}_{2}$ incubator in IMDM medium supplemented with $25 \mathrm{mM}$ HEPES, $10 \%$ fetal bovine serum, $1 \mathrm{mM}$ hypoxanthine, antibiotics (penicillin/streptomycin) and HMI-9 supplement. ${ }^{47}$ For screening purposes, parasites were distributed with $\backslash$ test compounds in 96-well plates at a final concentration of $10 \mu \mathrm{M}$ compound and $2.4 \times 10^{4}$ parasites per well in a total volume of $200 \mu \mathrm{l}$ per well. After a 24 hour incubation at $37{ }^{\circ} \mathrm{C}$ in a $5 \% \mathrm{CO}_{2}$ incubator, $20 \mu \mathrm{l}$ resazurin reagent $(0.5 \mathrm{mM}$ resazurin in phosphate-buffered saline) was added to each well and incubation continued for a further 24 hours. Resazurin conversion to resorufin was determined by measuring fluorescence $\left(\mathrm{Exc}_{560} / \mathrm{Em}_{590}\right)$ in a plate reader. Fluorescence values obtained in drug-treated wells were converted to \% parasite viability relative to readings obtained in control wells (non-treated parasites). Dose-response assays were performed by incubating parasites with 3 -fold serial dilutions of test compounds, plotting \% parasite viability $v s$. $\log \left[\right.$ compound] and determining $\mathrm{IC}_{50}$ concentrations by nonlinear regression analysis using GraphPad Prism. All assays were performed in technical triplicate.

\section{HeLa cell assay}

HeLa cells were cultured in DMEM medium supplemented with $10 \%$ fetal bovine serum and antibiotics (penicillin/ streptomycin/amphotericin B) at $37{ }^{\circ} \mathrm{C}$ in a $5 \% \mathrm{CO}_{2}$ incubator. On the day prior to compound addition, cells were plated in 96-well plates at $2 \times 10^{4}$ cells per well. Compounds were added to the cells in 3-fold serial dilutions and incubation at $37{ }^{\circ} \mathrm{C}$ in a $5 \% \mathrm{CO}_{2}$ incubator continued for 48 hours. Twenty $\mu \mathrm{l}$ resazurin reagent $(0.5 \mathrm{mM}$ resazurin in phosphatebuffered saline) was added to each well and, after a 2-hour incubation, fluorescence $\left(\mathrm{Exc}_{560} / \mathrm{Em}_{590}\right)$ was measured in a plate reader. Percentage cell viability in drug-treated wells was calculated from the fluorescent readings obtained relative to those in wells containing control, untreated cells. Plots of \% cell viability $v s . \log [$ compound] were used to determine $\mathrm{IC}_{50}$ values by non-linear regression analysis using GraphPad Prism.

\section{Conflicts of interest}

There are no conflicts to declare.

\section{Acknowledgements}

This study was supported by funds from the South African Medical Research Council. A copy of the Pathogen Box was provided by the Medicines for Malaria Venture.

\section{References}

1 P. Büscher, G. Cecchi, V. Jamonneau and G. Priotto, Lancet, 2017, 390, 2397-2409.

2 S. Aksoy, P. Buscher, M. Lehane, P. Solano and J. Van Den Abbeele, PLoS Neglected Trop. Dis., 2017, 11, e0005454, 1-6.

3 S. Patterson, M. S. Alphey, D. C. Jones, E. J. Shanks, I. P. Street, J. A. Frearson, P. G. Wyatt, I. H. Gilbert and A. H. Fairlamb, J. Med. Chem., 2011, 54, 6514-6530.

4 L. Ferrins, M. Gazdik, R. Rahmani, S. Varghese, M. L. Sykes, A. J. Jones, V. M. Avery, K. L. White, E. Ryan, S. A. Charman, M. Kaiser, C. A. S. Bergström and J. B. Baell, J. Med. Chem., 2014, 57, 6393-6402.

5 G. Patel, N. E. Roncal, P. J. Lee, S. E. Lee, J. Erath, A. Rodriguez, R. J. Sciotti and M. P. Pollastri, MedChemComm, 2014, 5, 655-658.

6 M. Witschel, M. Rottmann, M. Kaiser and R. Brun, PLoS Neglected Trop. Dis., 2012, 6, e1805, 1-10.

7 M. Berninger, I. Schmidt, A. Ponte-Sucre and U. Holzgrabe, MedChemComm, 2017, 8, 1872-1890.

8 K. Stuart, R. Brun, S. Croft, A. Fairlamb, R. E. Gürtler, J. Mckerrow, S. Reed and R. Tarleton, J. Clin. Invest., 2008, 118, 1301-1310.

9 M. Keita, B. Bouteille, B. Enanga, J.-M. Vallat and M. Dumas, Exp. Parasitol., 1997, 85, 183-192.

10 H. B. Tatipaka, J. R. Gillespie, A. K. Chatterjee, N. R. Norcross, M. A. Hulverson, R. M. Ranade, P. Nagendar, S. A. Creason, J. McQueen, N. A. Duster, A. Nagle, F. Supek, V. Molteni, T. Wenzler, R. Brun, R. Glynne, F. S. Buckner and M. H. Gelb, J. Med. Chem., 2014, 57, 828-835.

11 M. L. Sykes, J. B. Baell, M. Kaiser, E. Chatelain, S. R. Moawad, D. Ganame, J. R. Ioset and V. M. Avery, PLoS Neglected Trop. Dis., 2012, 6, e1896, 1-14.

12 L. A. T. Cleghorn, S. Albrecht, L. Stojanovski, F. R. J. Simeons, S. Norval, R. Kime, I. T. Collie, M. De Rycker, L. Campbell, I. Hallyburton, J. A. Frearson, P. G. Wyatt, K. D. Read and I. H. Gilbert, J. Med. Chem., 2015, 58, 7695-7706.

13 W. C. Van Voorhis, J. H. Adams, R. Adelfio, V. Ahyong, M. H. Akabas, P. Alano, A. Alday, Y. Alemán Resto, A. Alsibaee, A. Alzualde, K. T. Andrews, S. V. Avery, V. M. Avery, L. Ayong, M. Baker, S. Baker, C. Ben Mamoun, S. Bhatia and Q. Bickle, et al., PLoS Pathog., 2016, 12, e1005763, 1-23.

14 J. Jeong, G. Kim, C. Moon, H. J. Kim, T. H. Kim and J. Jang, PLoS One, 2018, 13, e0195595, 1-10.

15 T. Vila and J. L. Lopez-Ribot, Antimicrob. Agents Chemother., 2017, 61, e02006-16, 1-9. 
16 S. Preston, Y. Jiao, A. Jabbar, S. L. McGee, B. Laleu, P. Willis, T. N. C. Wells and R. B. Gasser, Int. J. Parasitol.: Drugs Drug Resist., 2016, 6, 329-334.

17 S. Duffy, M. L. Sykes, A. J. Jones, T. B. Shelper, M. Simpson, R. Lang, S.-A. Poulsen, B. E. Sleebs and V. M. Avery, Antimicrob. Agents Chemother, 2017, 61, e00379-17, 1-22.

18 N. Thorne, D. S. Auld and J. Inglese, Curr. Opin. Chem. Biol., 2011, 14, 315-324.

19 R. Sink, S. Gobec and S. Pecar, Curr. Med. Chem., 2010, 17, 4231-4255.

20 S. Brand, L. A. T. Cleghorn, S. P. Mcelroy, D. A. Robinson, V. C. Smith, I. Hallyburton, J. R. Harrison, N. R. Norcross, D. Spinks, T. Bayliss, L. Stojanovski, L. S. Torrie, J. A. Frearson, R. Brenk, A. H. Fairlamb, M. A. J. Ferguson, K. D. Read, P. G. Wyatt and I. H. Gilbert, J. Med. Chem., 2012, 55, 140-152.

21 J. A. Frearson, S. Brand, S. P. McElroy, L. A. T. Cleghorn, O. Smid, L. Stojanovski, H. P. Price, M. L. S. Guther, L. S. Torrie, D. A. Robinson, I. Hallyburton, C. P. Mpamhanga, J. A. Brannigan, A. J. Wilkinson, M. Hodgkinson, R. Hui, W. Qiu, O. G. Raimi and D. M. F. van Aalten, et al., Nature, 2010, 464, 728-734.

22 I. Y. Lee, T. D. Gruber, A. Samuels, M. Yun, B. Nam, M. Kang, K. Crowley, B. Winterroth, H. I. Boshoff and C. E. Barry, Bioorg. Med. Chem., 2013, 21, 114-126.

23 L. Ballell, R. H. Bates, R. J. Young, D. Alvarez-Gomez, E. Alvarez-Ruiz, V. Barroso, D. Blanco, B. Crespo, J. Escribano, R. González, S. Lozano, S. Huss, A. Santos-Villarejo, J. J. Martín-Plaza, A. Mendoza, M. J. Rebollo-Lopez, M. Remuiñan-Blanco, J. L. Lavandera and E. Pérez-Herran, et al., ChemMedChem, 2013, 8, 313-321.

24 I. Peña, M. Pilar Manzano, J. Cantizani, A. Kessler, J. Alonso-Padilla, A. I. Bardera, E. Alvarez, G. Colmenarejo, I. Cotillo, I. Roquero, F. De Dios-Anton, V. Barroso, A. Rodriguez, D. W. Gray, M. Navarro, V. Kumar, A. Sherstnev, D. H. Drewry and J. R. Brown, et al., Sci. Rep., 2015, 5, 8771.

25 Y. Nakamura, A. Suganami, M. Fukuda, M. K. amru. Hasan, T. Yokochi, A. Takatori, S. Satoh, T. Hoshino, Y. Tamura and A. Nakagawara, Cancer Med., 2014, 3, 25-35.

26 R. Behera, S. M. Thomas and K. Mensa-Wilmot, Antimicrob. Agents Chemother., 2014, 58, 2202-2210.

27 P. S. Shirude, P. Madhavapeddi, J. A. Tucker, K. Murugan, V. Patil, H. Basavarajappa, A. V. Raichurkar, V. Humnabadkar, S. Hussein, S. Sharma, V. K. Ramya, C. B. Narayan, T. S. Balganesh and V. K. Sambandamurthy, ACS Chem. Biol., 2013, 8, 519-523.

28 B. B. Das, T. Sengupta, A. Ganguly and H. K. Majumder, Mol. Microbiol., 2006, 62, 917-927.

29 A. Das, A. Dasgupta, T. Sengupta and H. K. Majumder, Trends Parasitol., 2004, 20, 381-387.

30 M. J. Almela, S. Lozano, J. Lelièvre, G. Colmenarejo, J. M. Coterón, J. Rodrigues, C. Gonzalez and E. Herreros, PLoS One, 2015, 10, 1-18.

31 Y. Younis, F. Douelle, T. S. Feng, D. G. Cabrera, C. Le Manach, A. T. Nchinda, S. Duffy, K. L. White, D. M.
Shackleford, J. Morizzi, J. Mannila, K. Katneni, R. Bhamidipati, K. M. Zabiulla, J. T. Joseph, S. Bashyam, D. Waterson, M. J. Witty and D. Hardick, et al., J. Med. Chem., 2012, 55, 3479-3487.

32 J. Okombo and K. Chibale, MedChemComm, 2018, 9, 437-453.

33 T. Paquet, C. Le Manach, D. G. Cabrera, Y. Younis, P. P. Henrich, T. S. Abraham, M. C. S. Lee, R. Basak, S. Ghidelli-Disse, M. J. Lafuente-Monasterio, M. Bantscheff, A. Ruecker, A. M. Blagborough, S. E. Zakutansky, A. M. Zeeman, K. L. White, D. M. Shackleford, J. Mannila and J. Morizzi, et al., Sci. Transl. Med., 2017, 9, eaad9735, 114.

34 C. W. McNamara, M. C. S. Lee, C. S. Lim, S. H. Lim, J. Roland, A. Nagle, O. Simon, B. K. S. Yeung, A. K. Chatterjee, S. L. McCormack, M. J. Manary, A. M. Zeeman, K. J. Dechering, T. R. S. Kumar, P. P. Henrich, K. Gagaring, M. Ibanez, N. Kato and K. L. Kuhen, et al., Nature, 2013, 504, 248-253.

35 M. J. Rodgers, J. P. Albanesi and M. A. Phillips, Eukaryotic Cell, 2007, 6, 1108-1118.

36 A. M. Gimenez, M. C. Gesumaría, A. C. Schoijet, G. D. Alonso, M. M. Flawiá, G. E. Racagni and E. E. Machado, Mol. Biochem. Parasitol., 2015, 203, 14-24.

37 C. Le Manach, A. T. Nchinda, T. Paquet, D. Gonzàlez Cabrera, Y. Younis, Z. Han, S. Bashyam, M. Zabiulla, D. Taylor, N. Lawrence, K. L. White, S. A. Charman, D. Waterson, M. J. Witty, S. Wittlin, M. E. Botha, S. H. Nondaba, J. Reader and L. M. Birkholtz, et al., J. Med. Chem., 2016, 59, 9890-9905.

38 C. Brunschwig, N. Lawrence, D. Taylor, E. Abay, M. Njoroge, G. S. Basarab, C. Le Manach, T. Paquet, D. González Cabrera, A. T. Nchinda, C. de Kock, L. Wiesner, P. Denti, D. Waterson, B. Blasco, D. Leroy, M. J. Witty, C. Donini and J. Duffy, et al., Antimicrob. Agents Chemother., 2018, 62, e00012.

39 R. Wilson, P. Kumar, V. Parashar, C. Vilchèze, R. VeyronChurlet, J. S. Freundlich, S. W. Barnes, J. R. Walker, M. J. Szymonifka, E. Marchiano, S. Shenai, R. Colangeli, W. R. Jacobs, M. B. Neiditch, L. Kremer and D. Alland, Nat. Chem., 2013, 9, 499-506.

40 S. Thanna, S. E. Knudson, A. Grzegorzewicz, S. Kapil, S. J. Sucheck, C. M. Goins, D. R. Ronning, M. Jackson, R. A. Slayden and S. J. Sucheck, Org. Biomol. Chem., 2016, 14, 6119-6133.

41 F.-J. Gamo, L. M. Sanz, J. Vidal, C. de Cozar, E. Alvarez, J.-L. Lavandera, D. E. Vanderwall, D. V. S. Green, V. Kumar, S. Hasan, J. R. Brown, C. E. Peishoff, L. R. Cardon and J. F. Garcia-Bustos, Nature, 2010, 465, 305-310.

42 M. Esposito, S. Szadocka, G. Degiacomi, B. S. Orena, G. Mori, V. Piano, F. Boldrin, J. Zemanová, S. Huszár, D. Barros, S. Ekins, J. Lelièvre, R. Manganelli, A. Mattevi, M. R. Pasca, G. Riccardi, L. Ballell, K. Mikušová and L. R. Chiarelli, ACS Infect. Dis., 2017, 3, 428-437.

43 C. Leija, F. Rijo-Ferreira, L. N. Kinch, N. V. Grishin, N. Nischan, J. J. Kohler, Z. Hu and M. A. Phillips, PLoS Pathog., 2016, 12, 1-30. 
44 J. A. M. Ali, D. N. A. Tagoe, J. C. Munday, A. Donachie, L. J. Morrison and H. P. de Koning, PLoS One, 2013, 8, e58034, 1-11.

45 P. N. Black, C. Ahowesso, D. Montefusco, N. Saini and C. C. Dirusso, MedChemComm, 2016, 7, 612-622.
46 S. B. Falconer, S. A. Reid-Yu, A. M. King, S. S. Gehrke, W. Wang, J. F. Britten, B. K. Coombes, G. D. Wright and E. D. Brown, ACS Infect. Dis., 2016, 1, 533-543.

47 H. Hirumi and K. Hirumi, J. Parasitol., 1989, 75, 985-989. 